\title{
Evaluation of the Impact of Good Governance on Sustainable Rural Development in Nigeria: A Study of Kaduna State
}

\author{
Lawal Bala Isa \\ Faculty of Administration, Ahmadu Bello University Zaria
}

\begin{abstract}
This paper evaluates the impact of good governance on rural development in Kaduna State. The problem investigated is stimulated by the expectation of the people for good governance in this democratic era. The specific objective of the study include determining the extent to which the government achieved the tenets of good governance, finding out the impact of good governance on rural development and examining the constraints of good governance in achieving rural development. Data for the study were generated from both primary and secondary sources using the instrument of observation, questionnaire, published and unpublished material as well as the internet. Data were analysed using both descriptive and inferential statistics. The descriptive tools used include tables and simple percentages while the inferential tool used is the spearman rank correlations. The study revealed that, good governance has not provided rural development. More specifically, there is low service delivery, low rate of adherence to rule of law, lack of transparency and accountability, existence of high rural poverty, decay in rural educational system, inadequate water and road infrastructure as well as inadequate health facilities. The study also revealed poverty, corruption, poor judicial system, as constraints for good governance. It was therefore recommended that, there should be institution of integrity, transparency and accountability in governance, there should be improvement in social services and there should be measures to check misgovernance and mismanagement.
\end{abstract}

Keywords: Good Governance, Development, Rural Development, Sustainable Development.

DOI: $10.7176 /$ RHSS/10-22-11

Publication date: November $30^{\text {th }} 2020$

\subsection{INTRODUCTION.}

\subsection{Background to the Study}

Good governance emerges as a product of emphasis on societal development, progress and sustainable growth (Ugwu, 2010.47). Indeed one way of measuring the success or failure of governments in modern society's world over is to assess how successful such governments are in developing the conditions for satisfying the basic needs of the people they govern (Basil, 2009:350). The needs include basic infrastructure; social services; creation of an efficient and productive economy. In addition, it also includes ability to mobilize or generate adequate resources as well as utilized them on the path of both urban and rural development (Ayo, 2009:19, citing Stohr, 1981:1-2).

Nigeria is one of those countries of the developing world that urgently requires rural sustainable development for her citizens through the instrumentalities of good governance. Ohagwu 2010, cited in (Shehu; 2015:2) opines that rural development is that part of development that seek to enhance the quality of life in the rural areas by providing basic infrastructural facilities, that include water supply, Health Care; road, transport and communication, education, agricultural facilities, markets and electricity.

Rural dwellers have rightfully asserted their place in the scheme of things in Nigeria, as they continued to provide the food needs of the urban population and also supply the raw materials for agro- based industries located in the semi-urban areas of the country. Although the rural inhabitants remain the life wire of the Nigerian economy; there is very little evidence to suggest that past policies of government made significant impact in terms of improving the quality of life of those categories of Nigerians (Ibrahim, 2014:2).

Finally, this paper is divided into five sections. Section one is the introduction, section two dwells on literature review and theoretical framework, section three contains the research methodology, section four centered on discussions of results and findings while section five concludes the paper with summary, conclusions and recommendations.

\subsection{Statement of the Problem}

In Kaduna State; the return of the country to a democratic rule in 1999, increased the demand of the people for good governance especially in the rural areas. Observation shows that in Kaduna State, most rural areas lack good water supply, motorable roads, rural electricity as well as educational and Health facilities. Hence, the problem highlighted by this paper is stimulated by the need to investigate if the rising expectations of the people for good governance and rural development have been met.

\subsection{Research Questions}

The research questions arising from the research problem are; to what extent does the government attain the tenets 
of good governance in rural areas? To what extent does good governance ensure rural development? And what constitute the constraints for good governance in the drive for rural development?

\subsection{Objectives of the Study}

The central objective of this paper is to determine the impact of good governance on rural development. However, specifically, the study seeks to find out the extent to which government achieved the tenets of good governance in rural areas; determine the extent to which good governance ensures rural development and examine the constraints of good governance in ensuring rural development.

\subsection{Hypothesis}

The null hypothesis postulated for this study is "there is no significant relationship between good governance and rural development"

\subsection{Significance of the Study}

Significantly, many studies have been conducted on the impact of good governance such as Abdulkarim (2004), Idris (2006), Ibrahim (2007), Basil (2009), and Ugwu (2010), but this study is unique for its focus on rural development. This will fill in the existing gap in these studies and new ideas will emerge from the present study on Kaduna State. This study is of tremendous importance to research, development policy makers and practitioners; international development agencies, the local governments and the general public. All these categories will benefit from the rich literature and data therein.

\subsection{Scope and Limitations of the Study}

This study spans between the period of (2007-2015) in Kaduna State. This can be justified on the ground that this is a democratic era in which the citizens expect benevolent performance on good governance. The period also coincided with the eight years of servant leadership experienced in Kaduna State. The study is also limited to three local governments; one from each senatorial zone. Thus, Igabi from Kaduna North, Kajuru from Kaduna South, as well as Soba from Kaduna Central were selected. The indices of good governance are emphasized including: citizens' participation, development oriented leadership, accountability, transparency and rule of law. As for rural development, emphasis is on infrastructural development in terms of water supply, roads, Health care, electricity and education. These indices also operationalize the concept of good governance and rural development.

\subsection{LITERATURE REVIEW AND THEORETICAL FRAMEWORK.}

\subsection{Introduction}

This section consists of conceptual clarification; review of previous related studies, theoretical framework and experience of other countries.

\subsection{Conceptual clarification}

Three concepts were explored in this study. These are good governance, development and rural development.

\subsubsection{Concept of Good Governance}

The Concept of good governance does not tend itself to a single definition. Ezeife (2002:36) sees good governance as the careful and guided application of government resources to the upliftment of standards of living of the society. Ademolekun $(2002: 3,2006: 31)$ sees governance as the exercise of political authority in managing the affairs of the state, he identified the indices of good governance as adherence to the rule of Law; freedom of expression and association; electoral legitimacy; accountability; transparency and development oriented leadership.

Sharma (2011:64) sees good governance as the ability to deliver goods to various stakeholders by making the various agents of political system work for the betterment of the people especially the marginalized section of the society.

\subsubsection{Concept of Development}

Development as a concept defies precise definition. This is because scholars and practitioners advanced definitions based on their orientation and social milieu. Ngu, (2014:3) sees development as a positive process of comprehensive transformation of economic, political and socio-cultural values and institutions towards substantial amelioration of societal values.

Gathaka and Wanjala (2012), cited in Idris (2009:30) see development as the process of planned mobilization and harnessing of a society's natural and human resources for the advancement of the social, economic and political wellbeing of a people.

Early scholars like seers (1969:3), cited in Shehu (2015:18), sees development in terms of addressing wide spread absolute poverty, inequality and unemployment.

\subsubsection{Concept of Rural Development.}

The term rural development has been variously defined. However, it is much more restricted conceptually and 
spatially to rural environment or areas (Shehu, 2015:5). The World Bank (1975:3) sees rural development as a strategy designed, to improve the economic and social life of a specific group of people the rural.

Also, Ijere (1992) sees it as agricultural development. As for Idode (1989) the term implies development limited to spatial occupational context. Drejomach in Ayichi (1995) defines rural development as a process of increasing per capital income and standard of living of rural population which is measured in terms of food and nutrition, health, education housing and security. Ndubusi (1992), cited in Mabel (2010:84) gave a more comprehensive definition of rural development as the development of moral, social, political, and economic potentialities of rural communities to enhance their self-reliance through the provision of appropriate infrastructures. They include pipe borne water, electricity, good roads, increase in people's political consciousness and participation to promote their moral and social wellbeing.

\subsection{Review of Empirical Studies}

The study by Abdulkarim (2004) entitled "Good governance at local government level and development in Nigeria" attempted to analyse the role of good governance in local government administration. The study assumed that the lack of accountability, transparency, qualified staff and independence are indicators of good governance. The study is similar to the present one in its usage of transparency and accountability as indices of good governance.

Another study by Idris (2006) entitled "Towards sustaining democracy for good governance in fourth republic Nigeria", it was revealed that adherence to rule of law, electoral legitimacy, as well as accountability and transparency were low and that the fourth Republic did not ensure good governance. It was therefore suggested that rule of law needs to be strengthened; public institutions need to be among other things.

Basil (2009) studied good governance and leadership in Africa, panacea for sustainable growth and development. To him, what is lacking is the proper leadership that could successfully harness the abundant, natural and human resources of Africa for sustainable growth and development.

Finally, Ugwu (2010) studies good governance accountability and development in Nigeria. The study revealed policy of clienlalism, poor judicial system and absence of procurement law as some of the constraints of good governance.

\subsection{Theoretical Framework}

The theoretical framework adopted far this study is the rural modernization theory. One of the proponents of this theory is Neil Smelser (1963). Rural modernization theory is often operationalised in infrastructure development policy. The theory posits that rural development can be attained through provisions of modern facilities in rural areas, so that they will also share features of modern urban areas.

Applying rural modernization theory to the study on the impact of good governance on rural development in Kaduna State, government is expected to be responsive, accountable and transparent in the provisions of schools and colleges in the rural areas. Establishment of health care centres and maternities, extensive rural water supply and electrification projects, provisions of rural feeder roads and so on. By this, the citizens will have trust in government and thus participate in decision making and improve the commercial interactions and overall well being in the rural populace.

\subsection{Methodology}

This section provides information on the research design adopted; sources and methods of data collection utilized; population and sample size of the study; sampling technique as well as methods of data analysis employed.

In terms of research design, this study adopted the survey research design. The use of survey design can be justified on the bases of economy, reliability, and rapid turnaround in data collection. This study was designed to investigate the impact of good governance on rural development. Variables relating to good governance and that of rural development were examined. The responses of the respondents were measured in the five point likert scale of Strongly Agree (SA), Agree (A), Undecided (U), Disagree (D) and Strongly Disagreed (SD).

In terms of sources and methods of data collection, the study utilized both primary and secondary sources of data. The primary sources used include observation, and questionnaire methods. This is justified on the bases of reliability, convenience, and preserving anonymity. The secondary source consists of books, magazines, newspapers; internet and unpublished materials. The secondary source compliments the primary sources.

The target population of the study consists of rural inhabitants in the selected local governments namely Igabi, Kajuru and Soba. It consists of 750 rural populace, 300 politicians, 410 staff of local governments, 200 members each of youth organizations and women group, 30 traditional rulers; 70 members of non-governmental organizations, as well as 120 community leaders totalling 2,081. The table below shows the distribution. 
Table 3.1 Population Distribution.

\begin{tabular}{|l|c|c|c|c|}
\hline \multicolumn{1}{|c|}{ Category } & $\begin{array}{c}\text { Kaduna North } \\
\text { Igabi }\end{array}$ & $\begin{array}{c}\text { Kaduna South } \\
\text { Kajuru }\end{array}$ & $\begin{array}{c}\text { Kadunda Central } \\
\text { Soba }\end{array}$ & Total \\
\hline Rural Populace & 200 & 250 & 300 & 750 \\
\hline Politicians & 90 & 110 & 100 & 300 \\
\hline Staff Of Local Governments & 100 & 140 & 170 & 410 \\
\hline Youth Organizations & 60 & 50 & 90 & 200 \\
\hline Women Group & 80 & 60 & 60 & 200 \\
\hline Traditional Rulers & 8 & 14 & 8 & 30 \\
\hline NGOs & 21 & 30 & 19 & 70 \\
\hline Community Leaders & 35 & 30 & 55 & 120 \\
\hline Total & $\mathbf{5 9 4}$ & $\mathbf{6 8 4}$ & $\mathbf{8 0 3}$ & $\mathbf{2 , 0 8 1}$ \\
\hline
\end{tabular}

Source: Researchers Computation 2020

From the population distribution above, the sample size is determined using Yamane's formular as thus;

$n=\frac{N}{1+N(e)^{2}}$

Where $\mathrm{n}=\quad$ Sample size

$\begin{array}{lll}\mathrm{N} & = & \text { Total population } \\ \mathrm{e} & = & \text { Level of significance }(95 \%)\end{array}$

Source: Yamane (1968) as expressed by Israel (1992)

Here:

335.5

$$
\begin{aligned}
n= & \frac{2,081}{1+2081(0.05)^{2}} \\
= & \frac{2,081}{1+20810.0025} \\
= & \frac{2,081}{1+5.2025} \\
& =\frac{2,081}{6.2025}
\end{aligned}
$$

\begin{tabular}{|c|c|c|c|c|c|}
\hline Category & $\begin{array}{c}\text { Kaduna } \\
\text { North Igabi }\end{array}$ & $\begin{array}{c}\text { Kaduna South } \\
\text { Kajuru }\end{array}$ & $\begin{array}{c}\text { Kadunda } \\
\text { Central Soba }\end{array}$ & $\begin{array}{c}\text { Kaduna North } \\
\text { Igabi }\end{array}$ & Percentage \\
\hline Rural Populace & 22 & 2 & 40 & 88 & \\
\hline Politicians & 16 & 23 & 10 & 49 & \\
\hline Local Gov'ts Staff & 10 & 15 & 30 & 55 & \\
\hline Youth Organizations & 7 & 8 & 10 & 25 & \\
\hline Women Group & 14 & 7 & 7 & 28 & \\
\hline Traditional Rulers & 3 & 6 & 4 & 13 & \\
\hline NGOs & 10 & 17 & 5 & 32 & \\
\hline Community Leaders & 7 & 12 & 27 & 46 & \\
\hline Total & 89 & 114 & 133 & 336 & \\
\hline
\end{tabular}

$\therefore \mathrm{n}=336$ representing $16.15 \%$ of the total population.

Based on the above sample size of 336, the sample distribution for questionnaire is as follows:

Table 3.2 Sample Size Distribution

\section{Source: Researchers Computation 2020}

The sampling technique adopted for the study in drawing the sample size is the simple random sampling technique. Also questionnaires were administered personally by the researcher with the aid of research assistants. Observation was carried out on state of infrastructure in the selected areas.

Finally, in terms of methods of data analysis both descriptive and inferential statistical tools of analysis were employed in the study. The descriptive tools included the use of frequency tables, simple percentages and mean scores for analysing and interpreting data. The inferential statistical tool used was the spearman's Rank correlation, being one of the non-parametic tools for measuring the degree of relationship between two variables " $\mathrm{X}$ " 
(Independent) and "Y" (dependent). The spearman's Rank correlation formula given as

$R=\frac{6 \xi d^{2}}{N\left(N^{2}-1\right)}$

Where $\quad d=\quad$ the difference between the ranks of

Corresponding values of $\mathrm{X}$ and $\mathrm{Y}$

$\mathrm{N}=\quad$ The number of pairs of values $(\mathrm{X}, \mathrm{Y})$ in the data.

The $\mathrm{R}$ value obtained from the formula are subjected to $\mathrm{t}$ - test to check significance as thus

$t=\frac{R \sqrt{N-2}}{\left(1-R^{2}\right)}$

Where $\mathrm{N}=$ number of values of $\mathrm{X}$ and $\mathrm{Y}$

Source: Spiegel and Stephens (1999).

The $t$ value obtained is then compared with the critic value of $t$ distribution at $95 \%(0.05)$ level of significance and given degree of freedom (v). The degree of freedom is equal to the number of the pairs of values of $\mathrm{X}$ and $\mathrm{Y}$ where $\mathrm{X}$ is the independent variable and $\mathrm{Y}$, the depended variable.

The decision rule in using $\mathrm{R}$ for testing hypothesis is as follows: accept null hypothesis Ho if $\mathrm{R}$ calculated value is less than the critical value, if otherwise reject.

\subsection{Discussion, Results and Findings}

4.1 Introduction

This section provides discussions on data presented, analysed and interpreted. It consists of rate of returns of questionnaires, socio-demographic characteristics of respondents, and measuring of variables for rural development, presentation on constraints, statistical testing of hypothesis as well as major findings.

\subsection{Rate of Returns and Response of Questionnaires}

Three hundred and thirty six (336) questionnaires equivalent to the sample size were administered to the sample respondents. Out of 336 questionnaires administered, 316 were returned given a rate of returns of 94.04\%. Also, out of the 316 questionnaires returned, 300 questionnaires were duly completed, given a rate of response of $89.3 \%$. The table below shows the rate of questionnaire returns and response.

Table: 4.1 Rate of Returns / Response of questionnaire

\begin{tabular}{|l|c|c|c|c|c|c|}
\hline $\begin{array}{c}\text { Category Of } \\
\text { Respond }\end{array}$ & $\begin{array}{c}\text { Kaduna } \\
\text { North } \\
\text { Igabi }\end{array}$ & $\begin{array}{c}\text { Kaduna } \\
\text { South } \\
\text { Kajuru }\end{array}$ & $\begin{array}{c}\text { Kadunda } \\
\text { Central } \\
\text { Soba }\end{array}$ & $\begin{array}{c}\text { No. Of } \\
\text { Questionnaire } \\
\text { Administered }\end{array}$ & $\begin{array}{c}\text { No. Of } \\
\text { Questionnaire } \\
\text { Returned }\end{array}$ & $\begin{array}{c}\text { No. Of } \\
\text { Questionnaire } \\
\text { Duly } \\
\text { Completed }\end{array}$ \\
\hline Rural Populace & 22 & 26 & 40 & 88 & 85 & 80 \\
\hline Politicians & 16 & 23 & 10 & 49 & 45 & 40 \\
\hline Local Gov't Staff & 10 & 15 & 30 & 55 & 54 & 54 \\
\hline Youth Organisation & 7 & 8 & 10 & 25 & 20 & 20 \\
\hline Women Group & 14 & 7 & 7 & 28 & 25 & 24 \\
\hline Traditional Rulers & 3 & 6 & 4 & 13 & 12 & 10 \\
\hline NGOS & 10 & 17 & 5 & 32 & 32 & 30 \\
\hline Community Leaders & 7 & 12 & 27 & 46 & 43 & 42 \\
\hline Total & 89 & 114 & 133 & 336 & 316 & 300 \\
\hline
\end{tabular}

Sources: Survey Research 2020.

From the above table; rate of returns and Response is computed as thus:

Rate of Returns $=$

\begin{tabular}{lcc}
\multicolumn{3}{l}{ No of Questionnaire Returned } \\
No of Questionnaire administered \\
$=316$ & $\mathrm{x}$ & 100 \\
$=336$ & & 1 \\
\hline $94.05 \%$ &
\end{tabular}

Rate of Response $=$ No of Questionnaire duly completed x 100

No of Questionnaire administered $\times 1$

$=300 \times \frac{100}{336}$
$=89.3 \%$


Based on the above; analysis of data in this study is on the basis of 300 respondents.

\subsection{Socio-Demographic Characteristic of Respondents}

Here, variables such as Gender; marital status, Age, Educational qualification and occupation were used to elicit information from the respondents and presented on table 5.2 below.

Table 4.2 Socio-Demographic Characteristic of Respondent

\begin{tabular}{|c|c|c|c|}
\hline Indices & Variables & Responses & Percentages \\
\hline GENDER & $\begin{array}{l}\text { Male } \\
\text { Female } \\
\text { Total }\end{array}$ & $\begin{array}{l}205 \\
95 \\
300\end{array}$ & $\begin{array}{l}68.3 \% \\
31.7 \% \\
100 \%\end{array}$ \\
\hline AGE & $\begin{array}{l}21-30 \\
31-40 \\
41-50 \\
51-60 \\
\text { above } 60 \\
\text { Total }\end{array}$ & $\begin{array}{l}60 \\
140 \\
80 \\
17 \\
3 \\
300\end{array}$ & $\begin{array}{l}20 \% \\
46.7 \% \\
26.7 \% \\
5.7 \% \\
1 \% \\
100 \% \\
\end{array}$ \\
\hline $\begin{array}{l}\text { EDUCATIONAL } \\
\text { QUALIFICATION }\end{array}$ & $\begin{array}{l}\text { Religious Education } \\
\text { Primary Certificate } \\
\text { Grade II/WAEC/NECO.GCE } \\
\text { OND/ND/NCE/A level } \\
\text { HND/Degree } \\
\text { Post graduate } \\
\text { Total }\end{array}$ & $\begin{array}{l}70 \\
72 \\
56 \\
90 \\
10 \\
2 \\
300 \\
\end{array}$ & $\begin{array}{l}23.3 \% \\
24.0 \% \\
18.6 \% \\
30 \% \\
3.3 \% \\
0.6 \% \\
100 \% \\
\end{array}$ \\
\hline OCCUPATION & $\begin{array}{l}\text { Famers } \\
\text { Traders/Artisans } \\
\text { Civil servants unemployed } \\
\text { Total }\end{array}$ & $\begin{array}{l}148 \\
70 \\
50 \\
32 \\
300\end{array}$ & $\begin{array}{l}49.3 \% \\
23.3 \% \\
16.6 \% \\
10.6 \% \\
100 \%\end{array}$ \\
\hline STATUS & $\begin{array}{l}\text { Rural Populate } \\
\text { Politicians } \\
\text { Local Gov't staff } \\
\text { Youth organization } \\
\text { Women group } \\
\text { Traditional Rules } \\
\text { NGOs } \\
\text { Community leaders } \\
\text { Total }\end{array}$ & $\begin{array}{l}80 \\
40 \\
54 \\
20 \\
24 \\
10 \\
30 \\
42 \\
300\end{array}$ & $\begin{array}{l}26.6 \% \\
13.3 \% \\
18 \% \\
6.6 \% \\
8 \% \\
3.3 \% \\
10 \% \\
14 \% \\
100 \% \\
\end{array}$ \\
\hline
\end{tabular}

\section{Source: Researcher's Computation 2020}

From the above table, it is clear that majority of the respondents are male farmers and rural populace. It also shows that the opinions were expressed by those in their active ages and those with reasonable educational qualification. Similarly, except for about 30 respondents, in addition to farming. 
4.4 Secondary Data on the Activities of Kaduna State Governments on Good Governance and Rural Development 2007- 2015

Total 4.3 Elements of good governance 2007-2015

\begin{tabular}{|c|c|c|}
\hline & INDICATORS & ASPECTS \\
\hline $\begin{array}{l}\text { PEOPLE ORIENTED } \\
\text { LEADERSHIP }\end{array}$ & $\begin{array}{l}\text { 1. Formation of people forum to enhance participation in } \\
\text { governance } \\
\text { 2. Monthly media briefings to educate the people on how } \\
\text { government operate. } \\
\text { 3. to interact with students and lecturers of Kaduna State extraction. } \\
\text { 4. Payment of backlog of gratuity to retirees. } \\
\text { 5. Release of counterpart funding to international donors mis- } \\
\text { programmes. }\end{array}$ & $\begin{array}{l}\text { Good } \\
\text { Governance }\end{array}$ \\
\hline $\begin{array}{l}\text { TRANSPARENCY, } \\
\text { AND } \\
\text { ACCOUNTABILITY } \\
\text { AND RULE OF LAW. }\end{array}$ & $\begin{array}{l}\text { 6. Constant declaration of state government account to the public. } \\
\text { 7. Establishment of human rights commission. } \\
\text { 8. Establishment of many high courts. } \\
\text { 9. Increase in salary of the Judiciary. }\end{array}$ & $\begin{array}{l}\text { Good } \\
\text { Governance }\end{array}$ \\
\hline $\begin{array}{l}\text { RESPONSIVENESS } \\
\text { AND } \\
\text { INCLUSIVENESS }\end{array}$ & $\begin{array}{l}\text { 10. Capacity building for civil servants. } \\
\text { 11. Increase and prompt payment of salaries. } \\
\text { 12. Inclusion of permanent secretaries in state executive council. } \\
\text { 13. Merit system through civil service exams. } \\
\text { 14. Payment of Annual salary bonus. } \\
\text { 15. Formation of Kaduna state vehicle inspection scheme. }\end{array}$ & $\begin{array}{l}\text { Good } \\
\text { Governance }\end{array}$ \\
\hline
\end{tabular}

Source: Kaduna State Government Publication, 2015.

Table 4.4. Elements of infrastructure, Kaduna State 2007/ 2015

\begin{tabular}{|c|c|c|}
\hline Subject & Indicators & Aspects \\
\hline Housing and Roads & $\begin{array}{l}\text { 1. Construction of Housing } \\
\text { 2. Providing a new look for Kunda as capital city. } \\
\text { 3. Rehabilitation of Roads } \\
\text { 4. Construction of rural Roads }\end{array}$ & Infrastructure \\
\hline HEALTH & $\begin{array}{l}\text { 5. Contraction and equipping of hospitals in rural areas. } \\
\text { 6. Free medical services to children, pregnant women and the } \\
\text { Aged. } \\
\text { 7. Signing of MOU with foreign medical experts. } \\
\text { 8. Free medical treatment on eye, and cancer. }\end{array}$ & Infrastructure \\
\hline EDUCATION & $\begin{array}{l}\text { 9. Engagement and support girl child education } \\
\text { 10. Settlement of Teacher claim. } \\
\text { 11. Provision of textbooks. } \\
\text { 12. Provision of Buses for transporting students. } \\
\text { 13. Payment of student allowances. }\end{array}$ & Infrastructure \\
\hline $\begin{array}{l}\text { LOCAL } \\
\text { GOVERNMENT }\end{array}$ & $\begin{array}{l}\text { 14. Supporting wards and district project. } \\
\text { 15. Granting } 25 \% \text { subsidy on sale of fertilizers. } \\
\text { 16. Release of funds for Local Government project. } \\
\text { 17. Extension of conditional cash transfer COT to Local } \\
\text { Governments. }\end{array}$ & Infrastructure \\
\hline
\end{tabular}

Sources: Adopted from progress report of Kaduna State Local government service commission. 2015. 


\subsection{Measurement of Good Governance}

Respondents' opinion on variables of good governance were presented on table 4.5 below

Table 4.5 Respondents' opinion on good governance

\begin{tabular}{|c|c|c|c|c|c|c|}
\hline $\begin{array}{l}\text { INDICES RELATING TO GOOD } \\
\text { GOVERNANCE }\end{array}$ & $\mathbf{S A}$ & $\mathbf{A}$ & $\mathbf{U}$ & D & SD & TOTAL \\
\hline $\begin{array}{l}\text { 1. Citizens participated in governance as } \\
\text { a result of high service delivery. }\end{array}$ & $\begin{array}{c}40 \\
(13.3 \%) \\
\end{array}$ & $\begin{array}{c}30 \\
(10 \%)\end{array}$ & $\begin{array}{c}10 \\
(3.3 \%)\end{array}$ & $\begin{array}{c}100 \\
(33.3 \%) \\
\end{array}$ & $\begin{array}{c}120 \\
(40 \%)\end{array}$ & $\begin{array}{c}300 \\
(100 \%)\end{array}$ \\
\hline $\begin{array}{l}\text { 2. Rate of adherence to the principles of } \\
\text { rule of law is high. }\end{array}$ & $\begin{array}{c}20 \\
(6.6 \%) \\
\end{array}$ & $\begin{array}{c}10 \\
(3.3 \%) \\
\end{array}$ & $\begin{array}{c}30 \\
(10 \%)\end{array}$ & $\begin{array}{c}140 \\
(46.6 \%) \\
\end{array}$ & $\begin{array}{c}100 \\
(33.3 \%) \\
\end{array}$ & $\begin{array}{c}300 \\
(100 \%) \\
\end{array}$ \\
\hline $\begin{array}{l}\text { 3. There is existence of development } \\
\text { oriented leadership. }\end{array}$ & $\begin{array}{c}80 \\
(26.6 \%) \\
\end{array}$ & $\begin{array}{c}60 \\
(20 \%)\end{array}$ & $\begin{array}{c}10 \\
(3.3 \%)\end{array}$ & $\begin{array}{c}90 \\
(30 \%)\end{array}$ & $\begin{array}{c}60 \\
(20 \%)\end{array}$ & $\begin{array}{c}300 \\
(100 \%)\end{array}$ \\
\hline $\begin{array}{l}\text { 4. Rate of accountability and } \\
\text { transparency within the three arms of } \\
\text { government is high. }\end{array}$ & $\begin{array}{c}15 \\
(5 \%)\end{array}$ & $\begin{array}{c}20 \\
(6.6 \%)\end{array}$ & $\begin{array}{c}5 \\
(1.6 \%)\end{array}$ & $\begin{array}{c}110 \\
(36.6 \%)\end{array}$ & $\begin{array}{c}150 \\
(50 \%)\end{array}$ & $\begin{array}{c}300 \\
(100 \%)\end{array}$ \\
\hline
\end{tabular}

Key: SA = Strongly Agreed, A = Agreed, U = undecided, D = Disagreed, SD = Strongly Disagreed

Source: Survey Research 2020.

From table 4.5 above, it is clear that about 220 respondents representing $73.3 \%$ disagreed that citizens participated in governance were as a result of high service delivery. Similarly, 240 respondents representing $79.9 \%$ claimed that there is low rate adherence to rule of law. Also from the table, opinion was divided on the existence of development oriented leadership. 150 (50\%) disagreed while 140 (46.6\%) agreed. Finally, the table shows that the rate of Accountability and transparency within the three arms of government is not high. 260 respondents representing $(86.6 \%)$ attested to this.

\subsection{Measurement of Rural Development}

Respondents' opinion on measurement of rural development is also presented on table 4.6 below.

Table 4.6 Respondents' opinion on rural development

\begin{tabular}{|c|c|c|c|c|c|c|}
\hline INDICES FOR RURAL DEVELOPMENT & $\mathbf{S A}$ & $\mathbf{A}$ & $\mathbf{U}$ & D & SD & TOTAL \\
\hline 5. Poverty is high in the rural areas. & $\begin{array}{c}120 \\
(40 \%)\end{array}$ & $\begin{array}{c}80 \\
(26.6 \%)\end{array}$ & $\begin{array}{c}30 \\
(10 \%)\end{array}$ & $\begin{array}{c}60 \\
(20 \%)\end{array}$ & $\begin{array}{c}10 \\
(3 \%)\end{array}$ & $\begin{array}{c}300 \\
(100 \%)\end{array}$ \\
\hline $\begin{array}{l}\text { 6. Water and roads infrastructure were } \\
\text { fully developed in the rural areas. }\end{array}$ & $\begin{array}{c}10 \\
(3 \%)\end{array}$ & $\begin{array}{c}5 \\
(1.6 \%) \\
\end{array}$ & $\begin{array}{c}5 \\
(1.6 \%) \\
\end{array}$ & $\begin{array}{c}180 \\
(59.9 \%) \\
\end{array}$ & $\begin{array}{c}100 \\
(33.3 \%) \\
\end{array}$ & $\begin{array}{c}300 \\
(100 \%) \\
\end{array}$ \\
\hline $\begin{array}{l}\text { 7. There is total decay and collapse of } \\
\text { the rural system. }\end{array}$ & $\begin{array}{c}150 \\
(49.6 \%)\end{array}$ & $\begin{array}{c}100 \\
(33.3 \%)\end{array}$ & $\begin{array}{c}20 \\
(6.6 \%)\end{array}$ & $\begin{array}{c}20 \\
(6.6 \%)\end{array}$ & $\begin{array}{c}10 \\
(3.3 \%)\end{array}$ & $\begin{array}{c}300 \\
(100 \%)\end{array}$ \\
\hline $\begin{array}{l}\text { 8. There are inadequate healthcare } \\
\text { facilities services. }\end{array}$ & $\begin{array}{c}140 \\
(46.6 \%)\end{array}$ & $\begin{array}{c}120 \\
(40 \%)\end{array}$ & $\begin{array}{c}5 \\
(1.6 \%)\end{array}$ & $\begin{array}{c}15 \\
(5 \%)\end{array}$ & $\begin{array}{c}20 \\
(3.3 \%)\end{array}$ & $\begin{array}{c}300 \\
(100 \%)\end{array}$ \\
\hline
\end{tabular}

Key: SA = Strongly Agreed, A = Agreed, U = undecided, D = Disagreed, SD = Strongly Disagreed

Source: Survey Research 2020.

From table 4.6 above, respondents revealed that poverty is high in the rural areas under study. 200 respondents representing $66.6 \%$ attested to this. It was further claimed that water and roads infrastructure were not fully developed in the rural areas. As high as 280 respondents representing $93.2 \%$ attested to this. Also, the table further revealed that there is total decay and collapse of the rural educational system and there are inadequate healthcare facilities for rural health services. 250 respondents representing $82.9 \%$ claimed the former while 260 respondents representing $86.6 \%$ attest to the latter.

\subsection{Constraints Of Good Governance}

Respondents' opinions on the factors or constraints to good governance to enhance rural development were presented to table 4.7 below.

Table 4.7 Respondents' opinion on constraints of good governance for rural development

\begin{tabular}{|c|c|c|c|}
\hline S/NO & CONSTRAINTS & NO. OF RESPONDENTS & PERCENTAGE \\
\hline 1 & Poverty & 280 & $93 \%$ \\
\hline 2 & Corruption & 250 & $83.3 \%$ \\
\hline 3 & Test for excess wealth & 190 & $63.3 \%$ \\
\hline 4 & Poor judicial system & 220 & $73.3 \%$ \\
\hline 5 & Personalization of public offices & 240 & $80 \%$ \\
\hline
\end{tabular}

\section{Source: Survey Research 2020.}

The table above shows poverty, corruption, test for excess wealth, poor judicial system and personalization of public offices as constraints of good governance that can hinder rural development. 


\subsection{Test of Hypothesis}

The hypothesis postulated states that: there is no significant relationship between good governance and rural development. The independent variable here is good governance while the dependent variable is rural development. Data relating to good governance were captured from table 4.5. While data relating to rural development were captured from table 4.6 respectively. The highest percentage for each of the variables is chosen and presented on Table 4.8 below:

Table: 4.8

\begin{tabular}{|c|c|c|c|c|c|c|}
\hline $\begin{array}{c}\text { No. Of } \\
\text { Variables }\end{array}$ & $\begin{array}{c}\text { Good } \\
\text { Governance } \\
\mathbf{X}\end{array}$ & $\begin{array}{c}\text { Rural } \\
\text { Development }\end{array}$ & $\begin{array}{c}\text { Ranking Of X } \\
\text { Rx }\end{array}$ & $\begin{array}{c}\text { Ranking Of Y } \\
\text { Ry }\end{array}$ & $\begin{array}{c}\text { Rx }-\mathbf{R y} \\
\mathbf{D}\end{array}$ & $\mathbf{D}^{\mathbf{2}}$ \\
\hline 1 & 40 & 40 & 3 & 4 & -1 & 1 \\
2 & 46.6 & 59.9 & 2 & 1 & 1 & 1 \\
3 & 30 & 49.6 & 4 & 2 & 2 & 4 \\
4 & 50 & 46.6 & 1 & 3 & -2 & 4 \\
\hline
\end{tabular}

$$
\begin{aligned}
\mathrm{R} & =\frac{1-6 \sum \mathrm{d}^{2}}{\mathrm{~N}\left(\mathrm{n}^{2}-1\right)} \\
& =\frac{1-6 \times 10}{4\left(4^{2}-1\right)} \\
& =\frac{1-60}{4(16-1)} \\
& =\frac{1-60}{60} \\
& =1-1=0
\end{aligned}
$$

Subject $r=0$ to test of significance at $95 \%$ and 4 degrees of freedom.

$$
\begin{aligned}
\mathrm{t} & =\mathrm{r} \frac{\sqrt{N-2}}{\sqrt{1-r^{2}}} \\
& =0 \frac{\sqrt{4-2}}{\sqrt{1-0^{2}}} \\
& =0 \frac{\sqrt{2}}{\sqrt{1-0}} \\
& =0 \times \frac{4}{4} \\
& =0 \times 1 \\
& =0 . \text { Calculated value }
\end{aligned}
$$

Critical value $=2.353$.

From the spearman's Rank correlation and test of hypothesis, the calculated value is less than the critical value and going by the decision rule, the null hypothesis which states that there is no significant relationship between good governance and rural development was upheld.

\subsection{Major Findings of the Study}

From data collected and analysed, the study reveals that good governance has not enhanced rural development in Kaduna state more specifically:-

1. Attribute of good governance was not sufficiently or adequately exhibited by leaders, in the sense that service delivery is low, rate of adherence to rule of law is also low. Also transparency and accountability was not pronounced in the three arms of the local governments reviewed.

2. The study revealed high rate of rural poverty, existence of total decay and collapse in rural educational system, there is inadequate healthcare facilities for rural healthcare services as well as the inadequacy of water supply and rural roads to enhance development.

3. Fundamental constraints like poverty, corruption, desire for excess wealth, personalization of public office as well as poor judicial system affected the development of rural areas in the study environment/areas.

\subsection{Conclusion and Recommendation}

From data collected and hypothesis tested, the study concludes that good governance has not provided rural development in Kaduna State. That is there is no significant relationship between good governance and rural development. 
Consequently, government public resources have undergone mismanagement, misuse and misapplication, hence the existence of bad governance which has made our rural areas to remain in perpetual poverty and underdeveloped.

Accordingly, this study proffers the following recommendation:-

1. There is the need for the institution of the culture of integrity, accountability and transparency in the three arms of government. Here, the executive arm must provide policies that eliminate corruption in governance; the legislature must pass relevant laws that ensure transformation of the rural areas while the judiciary must be truly independent to ensure adherence to rule of law.

2. There is the need for rural development by reducing poverty through improvement in the provision of social services, improvement in qualitative education, provision of adequate healthcare facilities, potable water supply as well as feeder roads.

3. To remove the constraints of good governance, there is the urgency of enthroning effective checks against misgovernance.

\section{References}

Abdulkarim S. (2004), Democracy and Good Governance at Local Government level. proceedings of 2004

National Conference Organised by the Department of Public Administration ABU Zaria, 9-12 March, 2004.

Adammolekun, L. (2006): Politics Bureaucracy and Development in Africa, Ibadan, Spectrum Books Ltd.

Augustine N. (2012); Research Methods in Political Science and Public Administration University of Lagos.

Ayichi D. (1995) Models of Rural development in Nigeria with special focus on ADPS Ebo E. C. et al; Rural development Nigeria concepts, processes and prospects. Enugu Auto century pub. Coy.

Ayo, Bamidele (2000), "Government Crisis in Nigeria: Tocqueville's Challenge and Response of African Scholar", in Adedeji et al (eds) People-Centre Democracy in Nigeria? The research for Alternative Systems of Government at the Grassroots. Nigeria: Heinemann Educational Books Publisher.

Basil (2009), Good Governance and Leadership in Africa. Nigerian Journal of Public Administration and Local Government, Vol. xiv, No.1 September, 2009.

Ezeife, C. (2002), "Leadership, Democracy and Good Governance” in Crystal international Magazine June, 2002, Abuja, Heritage Press Ltd.

Ibrahim Z. (2014). Assessment of the Impact of Local Government on Rural Development of Soba and Zaria Local Government Areas. On published MSC Thesis, A.B.U Zaria.

Idris M. (2006); Journal of Administrative Studies ABU Zaria Vol. 4, No. 3, July 2016.

Idris M. (2009), NEPAD and Development in Nigeria. Proceedings of Second National Conference, Faculty of Social and Management Sciences; Kaduna State University. Kaduna

Ijere M. O. (1992) Leadina issues in rural development, Enugu ACENA Publishers.

Isa L.B (2020): Effect of the Evaluation of the 2009 education reforms on Access and quality in selected Federal Institutions, Unpublished PhD thesis, Ahmadu Bello University, Zaria, Nigeria.

Ngu S. (2014), Development Administration a Theoretical and Pragmatic disposition; Ahmadu Bello University. Press Limited Zaria.

Ohagwu, C.A. (2010), Rural Development in Nigeria: Issues, Concepts and Practice, Enugu, John Jacoob's Classic Publishers.

Ozoemenam M. (2005); Social Science Research Methods for Policy and strategic studies Mai Dusa Academic Publishers Kaduna.

Sharma M. P. (2011), Public Administration in Theory and Practice, Kitab Mahal Publishers.

Shehu A. (2015). An Introduction to Development Administration in Nigeria. Jobe Erans Booksa and Publications Bida.

Shehu A. (2015). An Introduction to Rural Development in Nigeria. Blessed Concepts Prints Bida.

Shehu and Ezenwegbu (2016). Esearch Methodology in Social Science. Prestige Printing Press Bida.

Spieged and Stephens (1999); Statistics. MC graw-Hill London

Stohr, W. B. (2001), "Development from Blow", The Bottom-up and Peripheral-Inward Development Paradigm". In Development from below: The Dialectics of Regional Planning in Developing Countries ed. W. B. Stohr and D. R. F. Taylor (Chichester, England, New York: Willey).

Ugwa C. (2010), Good Governance, Accountability and due process in Nigeria. University of Nigerian Nsukka Publication.

World Bank Report (1975): Rural development sector policy paper Washington D.C. 